\title{
Tricyclic antidepressant overdose necessitating ICU admission
}

\author{
Coenraad F N Koegelenberg, Zirkia J Joubert, Elvis M Irusen
}

Tricyclic antidepressant (TCA) overdose necessitating intensive care unit (ICU) admission remains a significant problem in the Western Cape. In this retrospective study, we reviewed the course of life-threatening TCA overdose in our centre to identify potential prognostic indicators. TCA levels $>1000 \mathrm{ng} / \mathrm{ml}$ were associated with QT and QRS prolongation and convulsions. However, no single parameter predicted non-survival. The overall mortality of TCA overdose was very low. Our findings should encourage clinicians to offer medical care including ICU admission, if necessary, to patients with TCA overdose.

S Afr Med J 2012;102(5):293-294.
Tricyclic antidepressants (TCAs) are widely prescribed for several indications in South Africa. Modes of action include presynaptic serotonin and noradrenaline re-uptake inhibition, antagonism of peripheral alpha-1-adrenergic receptors, a membrane-stabilising effect on the myocardium and anticholinergic action. ${ }^{1,2}$ Overdose may result in convulsions, neurological and respiratory depression and cardiac arrhythmias. ${ }^{2}$

The lifetime prevalence of major depression in South Africa is $9.7 \% .^{3}$ Depression is linked to suicide ideation with an average of

Division of Pulmonology, Department of Medicine, Stellenbosch University and Tygerberg Academic Hospital

C F N Koegelenberg, MB ChB, MMed (Int), FCP (SA), MRCP (UK), Cert Pulm (SA), $\mathrm{PhD}$

Z J Joubert, MB ChB, MMed (Int), FCP (SA)

E M Irusen, $\mathrm{MB} \mathrm{ChB}, \mathrm{FCP}(\mathrm{SA}), \mathrm{PhD}$

Corresponding author: C F N Koegelenberg (coeniefn@sun.ac.za)
180 - 400 suicide attempts per 100000 in the depressed population, compared with 10 - 25 per 100000 in the non-depressed population. ${ }^{4}$ Other factors predisposing individuals to suicide attempts include female gender, physical illness, occupation and marital status. ${ }^{4}$

Despite South Africa's high prevalence of depression and wide use of TCA, we found no African study on TCA overdose. We describe the course of life-threatening TCA overdose in our centre to identify potential prognostic indicators.

\section{Methods}

In this retrospective analytical study, we reviewed admission records of the medical intensive care unit (ICU) and coronary care unit (CCU) of Tygerberg Academic Hospital from 1999 to 2008. Patients with a diagnosis of TCA overdose and a positive TCA level were included. The Health Research Ethics Committee of Stellenbosch University approved the study and the chief medical superintendent of Tygerberg Academic Hospital granted permission for anonymous data collection. 
General demographic data, concomitant diagnoses and intoxications, TCA levels, Glasgow coma scales (GCS), acute physiology and chronic health evaluation (APACHE) II scores, complications and outcomes were documented. Electrocardiogram (ECG) changes were reviewed and an antidepressant overdose risk assessment (ADORA) was performed for each subject. The ADORA score comprises 6 parameters, each assigned a value of 1: (i) QRS $>0.1 \mathrm{~ms}$; (ii) cardiac arrhythmias; (iii) GCS <14; (iv) seizures; (v) respiratory depression; and (vi) a systolic blood pressure $<90 \mathrm{mmHg}$. A score $>2$ is considered high risk for adverse outcomes. ${ }^{5}$ Descriptive statistics and chi-squared or Fisher's exact tests were performed on dichotomous categorical variables and $t$-tests were used for continuous data analysis. Data are displayed as means with standard deviation (SD), unless otherwise stated.

\section{Results}

A total of 61 patients $(26.0 \pm 10.4$ years $)$ were admitted with

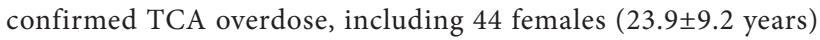
and 17 males $(30.6 \pm 11.7$ years, $p=0.015)$. Eleven patients $(18.0 \%)$ were on treatment for depression and $13(21.3 \%)$ had a history of deliberate self-harm. TCA levels on admission varied from $>1000 \mathrm{ng} / \mathrm{ml}(n=33)$ to $500-1000 \mathrm{ng} / \mathrm{ml}(n=16), 300-500 \mathrm{ng} /$ $\mathrm{ml}(n=8)$ and $<300 \mathrm{ng} / \mathrm{ml}(n=4)$. Twenty-five patients $(41.0 \%)$ ingested combinations of other substances, including ethanol $(n=9)$, paracetamol $(n=6)$, benzodiazepines $(n=6)$, beta-blockers $(n=3)$, opiates $(n=2)$ and anti-epileptics $(n=2)$.

Common reasons for ICU admission were decreased levels of consciousness $(n=49)$ and/or respiratory depression necessitating mechanical ventilation $(n=47)$. Related indications included convulsions $(n=15)$, dysrhythmias $(n=9)$, hypotension $(n=14)$ and severe metabolic acidosis $(n=6)$. ECGs on ICU admission showed a QT interval $>0.43 \mathrm{~s}$ in 31 patients and a QRS duration of $>0.12 \mathrm{~s}$ in 9 patients; both were associated with TCA levels $>1000 \mathrm{ng} / \mathrm{ml}$ ( $p=0.026$ and $p<0.001$, respectively). TCA levels $>1000 \mathrm{ng} / \mathrm{ml}$ were also associated with the risk for convulsions $(p=0.017)$. Eight patients developed serious ventricular dysrhythmias (sustained ventricular tachycardia and ventricular fibrillation) after admission; all responded to routine measures. Twelve patients had aspiration pneumonia.
In total, 21 patients had high-risk ADORA scores. The mean APACHE II score was $12.4 \pm 9.0$. The mean duration of ICU admission was 4.7 days (range 1 - 12); this did not correlate with the ADORA score, APACHE II score or TCA levels.

Three patients died ( $4.9 \%$ mortality); 2 from complications related to aspiration pneumonia and 1 from refractory shock secondary to concomitant beta-blocker overdose. The ADORA score, APACHE II score or TCA levels failed to predict these cases.

\section{Discussion}

We found a very low mortality rate with TCA overdose, consistent with a study from Iran. ${ }^{6}$ Remarkably, no patient died from cardiac arrhythmia or other direct toxic sequelae of the TCAs, despite a higher incidence of QT prolongation and ventricular arrhythmias in the study population compared with most other studies., ${ }^{2,5,5-7}$ Therefore, clinicians working in resource-constrained healthcare systems should offer medical care including ICU admission, if necessary, to patients with TCA overdose.

Limitations of our study include its retrospective nature. In addition, only patients admitted to ICU or CCU were included; patients who may have died in the emergency room, en route to Tygerberg Hospital or before transfer from referring institutions were excluded. Therefore, the mortality of serious TCA overdose may be higher than observed.

\footnotetext{
References

1. Mann JJ. Medical management of depression. N Engl J Med 2005;353:1819-1834. [http://dx.doi. org/10.1056/NEJMra050730]

Kerr GW, McGuffie AC, Wilkie S. Tricyclic antidepressant overdose: a review. Emerg Med J 2001;18:236-241. [http://dx.doi.org/10.1136/emj.18.4.236]

3. Tomlinson M, Grimsrud AT, Stein DJ, Williams DR, Myer L. The epidemiology of major depression in South Africa: results from the South African stress and health study. S Afr Med J 2009;99:367-373.

4. Unverir P, Atilla R, Karcioglu O, Topacoglu H, Demiral Y, Tuncok Y. A retrospective analysis of 4. Unverir P, Atilla R, Karcioglu O, Topacoglu $\mathrm{H}$, Demiral Y, Tuncok Y. A retrospective analysis of
antidepressant poisonings in the emergency department: 11 years experience. Hum Exp Toxicol 2006;25:605-612. [http://dx.doi.org/ doi:10.1177/096032706072470]

5. Foulke GE. Identifying toxicity risk early after antidepressant overdose. Am J Emerg Med 1995;13:123126. [http://dx.doi.org/10.1016/0735-6757(95)90076-4]

6. Dianat S, Zarei MR, Hassanian-Moghaddam H, Rashidi-Ranjbar N, Rahimian R, Rasouli MR. Tricyclic antidepressants intoxication in Tehran, Iran: epidemiology and associated factors. Hum Exp Toxicol 2011;30:283-288. [http://dx.doi.org/10.1177/0960327110371701]

7. Hulten BA, Adams R, Askenasi R, et al. Predicting severity of tricyclic antidepressant overdose. J Toxicol Clin Toxicol 1992;30:161-170. [http://dx.doi.org/10.3109/15563659209038628]
} 